\title{
METHODOLOGICAL APPROACHES ON INTERPRETATION CONCEPT "QUALITY" AND "QUALITY OF EDUCATION"
}

\begin{abstract}
This article focuses on the issues of methodology of the concepts of "quality" and "quality of education" in the relevant regulatory documents and views of the researchers from the ancient - and to our times.

The new philosophy of quality is a general category. In addition to products (goods) and services, it generically applies to enterprises, organizations, institutions, their personnel, and management systems. And nowadays, the term "quality" means not only the high quality of goods but also, above all, the way of management, as well as life.

In the recent years the issue of the quality of educational services in higher education has gained considerable popularity both in the civil society and in the world. The modern educational paradigm considers this concept as a multifaceted model of social norms and requirements for a personality, an educational environment in which its development and development of a system of education that implements educational tasks at certain stages of study in higher education institutions takes place.

It does comprise everything: the quality of the teaching and methodological base, the quality of teaching staff and teaching staff, the quality of providing educational services, the high degree of satisfaction of educational needs of students and, finally, the quality of the subject of learning.

The quality of education is a generalized indicator of the development of a society in a particular temporal dimension, and therefore it is considered in the dynamics of changes characterizing the state's progress in the context of the latest world trends. The International Standard also regulates the concept of "quality of education" as a set of properties and characteristics of the educational process that meet the educational needs of consumers of educational services.

All these are worldview concepts that have a methodological value to ensure the high quality of education at all stages and levels.

Keywords: methodological approach; the concept of "quality"; "the quality of education"; essence; definition; interpretation; a transformation of ideas; needs, expectations of consumers.
\end{abstract}

Formulation of the problem. In our time, the question of the methodology of the concept of "quality" has been drawing attention of specialists of all branches of science, which complies with the current the needs in the economic and political development of the Ukrainian society.

Quality related matters are universal and widespread in all the countries of the world, and they acquire a new particular urgency as market relations further, the competition becomes ever fierce, effective quality management systems are gradually implemented.

To a certain extent, these questions relate to education, where a new generation of professionals capable of ensuring the country's development in the post-industrial, informational era acquires knowledge.

The world community has recognized higher education as one of the most effective institutions, where the outlook and behavior are formed, the educative, scientific and cultural center is created, in fact, the destiny of each graduate and the future of society as a whole are laid down.

The problem of the quality of education, its effective functioning has always been the subject of scientific and practical interest of teachers. Therefore, considering the question of the quality of education, we, first of all, define the essence of the concept of "quality ", which has philosophical, historical and cultural, social dimensions and is the methodological basis for the concept of "quality of education".

Research objectives. The objective is to substantiate methodological approaches to the interpretation and transformation of the concepts of "quality" and "quality of education".

Analysis of recent researches and publications. The paper analyzes publications, the subject of research of which were questions, in one or another way related to methodological approaches to general questions "methodological approach", "quality" and "quality of education".

Since the late 1990s, these problems have been actively explored by researchers, which is reflected in the scientific searches of Anisimov O. S., Bakhtiarovoy H. S., Belyaeva AP, Viktor V. V., Kraevsky V. V., Kravchenko L.T. Kremenya V.T. Sukhova NM, Subetto A.I. and other.

The basis of the methodology of the issues under consideration is the fundamental conclusions of international and domestic documents, among which are State standards of Ukraine (USSR) 2925-94 "Quality of Products", SSOU 3230-95 "Quality management and quality assurance.
Terms and definitions" law and legislation of Ukraine. [1;2; $3 ; 4 ; 5 ; 6 ; 7 ; 8 ; 9 ; 12 ; 13 ; 14 ; 15 ;]$.

Research presentation. First of all, we specify the definition of the concepts "methodological approach", "quality", "quality of education".

In the "Ukrainian Pedagogical Dictionary" of the famous Ukrainian scientist Semen Goncharenko, the methodology understands "a set of methods of research applied in a science" [6, p. 207].

In the well-known dictionary I. O. Ozhegov the term "approach" is interpreted as "a combination of methods, methods of considering something, influence on someone, something, the attitude of someone, something" [13, p.471] Z.K. Maretukova equates the concept of "approach" with the concept of a new direction or position:" The concept "approach" in conjunction with the notion "methodological" can be interpreted as a methodological direction, as a methodological position (from the Latin rosition- position, assertion, point of view), which is a theoretical new formation with respect to traditional methodological foundations [12, p.25] I.V.Blauberg and E.G. Judin, describing the systematic approach, points out that this is a specific area of the methodology of specialized scientific knowledge and specialist practice, the concept or principle that governs the general research strategy [4].

Summarizing different views, the concept of a methodological approach can be defined as a specific point of view, position, view on a particular object being studied, which orientates the researcher in a certain way of knowing this object and its impact on it. In pedagogical research, the subject of analysis is education and various aspects of its implementation. In our case, this is a methodological approach to the concepts of "quality" and "quality of education," as well as the analysis and evaluation of these concepts from philosophical, ideological positions. The significance of the methodology of scientific knowledge lies in the fact that it allows to systematize all the amount of scientific knowledge and create conditions for the development of further useful research directions. The main task of the methodology of scientific knowledge is the synthesis of accumulated scientific knowledge, which allows ensuring the use of advances in the development of a particular science for practical purposes to ensure the quality of the studied processes.

The use of the term "quality" from the philosophical maxim turned into a lexicon of purely applied activity while preserving

(c) Bakhtiyarova Kh., 2019 
the philosophical content - quality is the basis for further improvement of products from various spheres of human life.

Therefore, today, more and more quality and economy, quality and culture, quality and spirituality are combined, and after all - all this is the quality of our lives. And in this sense, variety is the social morality and philosophy on which depends on who we are and what our society should be.

If you make a small excursion into history, you can find out that for the first time the quality problem was analyzed by Aristotle back in the fourth century. B.C. based on the fundamental definition, formulated in his time by Hegel, the quality should be understood objectively existing set of properties and characteristics of the object, which determines its essence and distinguishes it from the other.

Nevertheless, the Hegelian and much more recent definition of the category of quality reflects the vital aspect of the actual activity of the subject - certainty.

Conceptual approaches to the interpretation and transformation of the concept of "quality"

Table 1

\begin{tabular}{|c|c|}
\hline Author of Formulation & Formulation of Definition of Quality \\
\hline Aristotle (IV century BC) & Difference between objects. Differentiation based on "good - bad" \\
\hline Hegel (XIX century) & $\begin{array}{l}\text { Quality is primarily identified with the existence of certainty, that is, somewhat ceases to be } \\
\text { what it is, if it loses its quality. }\end{array}$ \\
\hline The Chinese version & $\begin{array}{l}\text { The Chinese version of the Hieroglyph defines that quality consists of two elements - "equilib- } \\
\text { rium" and "money" (quality = equilibrium + money). Consequently, the quality is identical to the } \\
\text { concept of "high-class", "dear". }\end{array}$ \\
\hline Walter A. Shewhart (1931) & Quality has two aspects: objective physical characteristics, subjective: how good is the thing. \\
\hline Taguhi (1940) & Quality is the cost to society due to untimely delivery and ineffective use of products. \\
\hline E. Deming (1950) & $\begin{array}{l}\text { Quality is the satisfaction of consumers' needs not only according to their expectations but } \\
\text { also predict the direction of their future changes. }\end{array}$ \\
\hline K. Ishikawa (1950) & Quality - a property that fully satisfies consumers. \\
\hline Great Soviet Encyclopedia (1956) & $\begin{array}{l}\text { Quality is a subjective and universal characteristic of an object, which manifests itself in the } \\
\text { totality of its properties. }\end{array}$ \\
\hline J. M. Juran (1979) & $\begin{array}{l}\text { Suitability for use (conformity to purpose). Quality is the degree of customer satisfaction (for } \\
\text { its implementation, the manufacturer must determine the requirements of the consumer and } \\
\text { make their products so that it meets these requirements). }\end{array}$ \\
\hline Government standard (GOST) 15467-79 & $\begin{array}{l}\text { The quality of products - a set of product properties that determine its suitability to meet needs } \\
\text { following its purpose. }\end{array}$ \\
\hline Government standard (GOST) 15467-79 & $\begin{array}{l}\text { The quality of products - a set of product properties that determine its suitability to meet needs } \\
\text { following its purpose. }\end{array}$ \\
\hline F. Crosby (1980) & Quality - Compliance. \\
\hline SSOU ISO 8402-86 & $\begin{array}{l}\text { Quality - a set of properties and characteristics of products or services that give it the ability } \\
\text { to meet the predicted or foreseeable needs. }\end{array}$ \\
\hline Edward Feigenbaum (1990) & $\begin{array}{l}\text { Quality is the correspondence of product or service characteristics, including marketing, } \\
\text { development, production and service, consumer expectations. Quality is not evangelism, it is } \\
\text { not innovation, not a slogan, but a way of life }\end{array}$ \\
\hline $\begin{array}{l}\text { SSOU ISO } 2925-94 \\
\text { SSOU ISO } 3230-95\end{array}$ & $\begin{array}{l}\text { Quality is a set of characteristics of products (processes, services) that relate to its ability to } \\
\text { meet the established and foreseeable needs of humanity. }\end{array}$ \\
\hline Yu Adler (2001) & Quality is what satisfies the consumer. \\
\hline SSOU ISO 9000-2001 & haracteristics meets requirements. \\
\hline
\end{tabular}

The International Organization for Standardization (ISO), and also regulatory documents of Ukraine defines quality as a "set of properties and characteristics of products or services (object) that enable them to meet the preconditions or foreseen needs of mankind."

ISO standards consider quality as the degree to which a set of own characteristics meets requirements. From this, it follows that the higher the ability of products to meet the needs of society, the higher its quality.

So, as a product of labor, the quality of a product is a category that is inextricably linked with the concepts of "good - bad", "better-worse", "above-below".

Some additional sources determine quality as "fitness for use," "compliance with the purpose," "satisfying the needs of consumers," "responsibility to standards and certain conditions."

In Ukraine, the unity of terminology, indicators, and methods for establishing the level of quality is ensured through a series of normative and technical documents (NTDs) developed by the State Research Institute "System" of State committee of Ukraine for technical regulation and consumer policy.

As we could see, today there are many different aspects of the concept of "quality" associated with economic, social, legal, managerial factors, etc. The variety of existing interpretations of the category, the quality of the existing ones can be conventionally combined into the following groups:
1. Quality as an absolute assessment - a sign of indisputable responsibility to the requirements of standards;

2. Quality as a property of the product - characterizes the entire spectrum of the utility of products for the consumer;

3. Quality as a purpose - the ability to perform specific functions;

4. Quality as the correspondence of values - the ratio of utility and product prices;

5. Quality as compliance with standards - compliance with the requirements of regulatory documents;

6. Quality as an ecological category - the degree of suitability of products for its consumption by purpose;

7. Quality as a legal category - compliance with actual and production properties of products provided for in the law, contract or regulation.

Definition of the category "quality" with the use of the phrase "needs and expectations of consumers" has recently become the subject of increased attention of educators in connection with the reform of higher education and the need for radical modernization of higher education institutions. Since the Law of Ukraine "On Education" is based on the changes in culture regarding the reorganization of institutions of higher education, it is the responsibility of the government to regulate the quality of education and measure the quality of education, and also the issue of implementing 
the quality management education system is now very relevant [11]. The quality of education determines a set of indicators characterizing various aspects of educational activity: content of education, forms, and methods of training, material and technical base, staffing, quality education management. The quality of education as a result of the institution of higher education indicates that the level of preparation of students for the requirements of the existing educational programs corresponds.

The problem of the quality of education was initially embraced by foreign pedagogy, and today it is recognized as a priority among the problems of the XXI century. The modern educational paradigm considers this concept as "a multi-faceted model of social norms and requirements for a person, an educational environment in which the development and development of a system of education that implements it at certain stages of human learning takes place"; as "a complex of characteristics of the educational process, which determine the consistent and effective formation of competence and professional consciousness; as a set of properties of the educational process that meet the educational needs of future specialists in a certain field of knowledge" [5].

By integrating the thoughts of different authors, we distinguish at least three groups of characteristics.; the quality of the achievement of the goal of education, the quality of the process of formation of professionalism and the quality of learning outcomes.
This imposes an imprint on the content, understanding, and interpretation of the category "quality of education". The diversity of existing definitions of this concept can be conventionally combined into such groups:

- the quality of education is a set of systemic and social attributes and characteristics that determine the responsibility of education systems for eligible requirements, social norms, and state educational standards;

- the quality of education is a complex character of the educational process, which determines the consistent and practically effective formation of competence and professional consciousness;

- the quality of education is the ability to perform the tasks set by society in shaping and developing particularities in the aspects of its teaching and education.

International experts consider the concept of quality of education as a subjective term identical to beauty and wellbeing; as a social category that identifies the status and effectiveness of the education process in society, its conformity to the needs and expectations in the formation and development of life and professional competences of the individual; as a characteristic organized in this or that educational system, which causes the adaptation to the realization of the primary goal of the formation of personality [14].

With these definitions, the words of prominent philosophers are also called out:

Conceptual approaches to the interpretation and transformation of the concept of "quality of education"

Table 2

\begin{tabular}{|l|l|}
\hline \multicolumn{1}{|c|}{ Author of Formulation } & \multicolumn{1}{c|}{ Formulation of Definition of Quality } \\
\hline Wilhelm von Humboldt & "mastering the necessary amount of knowledge", "optimal organization of the life of universities" \\
\hline Karl Jaspers & "Realistic Perception of Acquired Knowledge" \\
\hline M. Danilevsky, P. Sorokin, A. Toynbee & "mastering a common culture" \\
\hline Max Weber & The ability "to find its place in the system of productive and social relations" \\
\hline Alvin Toffler & "Effective management of technical social systems" \\
\hline
\end{tabular}

Domestic legislation on the quality of education understands the degree of correspondence of acquired knowledge, skills and abilities of students to the requirements of higher education standards [9].

In this sense, the quality of education should be understood as the balanced conformity of the process, the result and the educational system itself with the purpose, needs and social norms (standards) of education. Yes, according to Art. 22 of the Law of Ukraine "On Higher Education", the main purpose of the NGO's activity is to provide the conditions necessary for obtaining a person of higher education, scientific and scientific-technical, creative, educational, recreational activities, training of scientific and scientific and pedagogical personnel, as well as provision of cultural and spiritual development of personality and execution of state orders and agreements for the training of specialists, studying the demand for individual specialties in the labor market and promotion of employment [10]. In this context, it should be recalled that the effectiveness of any activity depends on the successful methodology - the system of principles and methods for organizing and constructing theoretical and practical activities. Modern pedagogical theory and practice are based on a large number of conceptual foundations. That is why the European models of education are mainly focused on the following world conceptual approaches:

- confirmation of the priority of the "consumer" assessment over the "manufacturer";

- comprehensive consideration of the quality problem through the creation of key elements / educational standards, the framework of professional competences, educational programs, etc.;
- determining the rating of institutions of higher education on the main educational parameters;

- thorough assimilation of a wide range of expert knowledge, skills, and abilities of their practical use;

- be competitive in the labor market;

- quality of teaching staff and professors;

- meeting the educational needs of an adult in the conditions of modern life of society.

Conclusions. Consequently, considering the methodological approaches to integrating the concepts of "quality" and "quality of education", it is logical to conclude that these are multidimensional, comprehensive, ideas that reflect social life.

In broad terms, the quality of education is an essential guarantor of the preservation and growth of the intellectual potential of society, a factor of social stability, the economic well-being of the country, its competitiveness and national security. Providing high-quality education at all stages and levels, assessing the quality achieved, comparative research is a challenge today, which has not only pedagogical but also social, political, managerial, and purely scientific contexts.

\section{References}

1. Anisimov O.S. Methodological culture of pedagogical activity and thinking / O.S. Anisimov Economics, 1991. - 415 pp.

2. Bakhtiyarova H.Sh. Proficiency monitoring of education quality in the engineering-pedagogical branch / H.Sh. Bakhtiyarova // Problems of formation of education in Ukraine [sec. Sciences of Art. 51] / in the sciences. Ed. SV Volobueva - K.: Education of Ukraine, 204 - From 83-96.

3. Belyaeva AP Methodology and theory of professional pedagogy / AP Belyaev - St. Petersburg, $1999-180 p$

4. Blauborg IV, Formation and essence of a systemic campaign / IV Blauborg, E.HYudin.- Moscow: Nauka, 1973-270 p. 
5. Victorov V.T. Management of quality of education: socio-philosophical analysis [monograph] / V.T. Victor - Dnipropetrovsk: Thresholds, 2005. - 286 p.

6. Goncharenko S. U. Ukrainian Pedagogical Dictionary / S.U. Goncharenko Reference edition. Kyiv: "Lybid" at the Kyiv State University, 1997 - 366 p.

7. Kraevsky V.V. Methodology of pedagogy / VV Kraevsky - Cheboksary: the publication of Chuvashi University., 2001. - $208 \mathrm{pp}$.

8. Kravchenko L.T. Problem of quality in philosophy, Historical and methodological essay / L.T. Kravchenko - Me: Thought., 1971 - 103s.

9. Kremen V.T. Philosophy of Education of the XXI Century / VT Kremen // High school - No.6 - 2002 - P. 9-17

10. Law of Ukraine "On Higher Education" September 28, 2017

11. The Law of Ukraine "On Education" of December 18, 2018, No. $2657-$ VIII, dated 20 December 2018, No. 2661-VIII.

12. Meretukova Z.K. Methodology of scientific research and education: study. Way. for students engaged in research and development of postgraduate studies / Z.K.Meretukova. - Meikop: Publishing-AGU, 2003. - 244 p.
13. Ozhegov S.I. Dictionary of the Russian Language / S.I. Ozhegov. - M.: Soviet Encyclopedia, 1973.-847 p. 14.

14. Sukhova N.M Quality of Higher Education as One of the Philosophical Foundations of the Transformation of Education in the 21st Century: European Context [Electronic Resource] / N.M. Sukhova - access mode: http://www.nbuv.gov.ua/portal/soc gum/Vnau f/2009 1/suxov.pdf.

15. Subetto A.I. The problem of higher education quality in the context of globalized and national problems of social development (philosophy of quality of education) / Al Subetto - spb.; Kostroma, 2000. - 189 p.

16. Fundamentalization of vocational training in the dimension of the European educational space: / M. F. Dmitrichenko, H. Sh. Bahtiyarova, N. M. Glushenok, M. Khmelevsky B. I. Khoroshun, A. M. Yavenskaya - K.: NTU, 2013. - $276 \mathrm{pp}$.

Надійшла до редколегії 12.03.19

Х. Бахтіярова, канд. пед. наук, доц., проф.

Національний транспортний університет, Київ, Україна

\section{МЕТОДОЛОГІЧНІ ПІДХОДИ ЩОДО ІНТЕРПРЕТАЦІї ПОНЯТЬ "ЯКІСТЬ" ТА "ЯКІСТЬ ОСВІТИ"}

Розелянуто питання методології понять "якість" та "якість освіти" у нормативних документах та поглядах дослідників з античних - $і$ до наших часів.

Нова філософія якості - це катееорія всеохоплююча. Крім продукції (товарів) та послуг вона поширюється на підприємства, організації, установи, їхній персонал і системи менеджменту. І в наш час термін "якість" означає не лише високу якість товарів, а й передусім - спосіб управління, а також життя.

Останнім часом суттєвого поширення в суспільстві та світі здобули питання якості надання освітніх послуг у вищій школі. Сучасна парадигма освіти розглядає це поняття як багатогранну модель соціальних норм і вимог до особистості, освітнього середовища, в якому відбувається ї̈ розвиток та розвиток системи освіти, що реалізує освітні завдання на певних етапах навчання у закладах вищої освіти.

Тут інтегрується все: якість навчально-методичної бази, якість педагогічних кадрів та професорсько-викладацького складу, якість надання освітніх послуг, високий ступінь задоволення освітніх потреб студентів $і$, нарешті, якість самого суб'єкта навчання.

Якість освіти - це узагальнений показник розвитку суспільства в певному часовому вимірі, а тому його розглядають в динаміці змін, що характеризують поступ держави в контексті новітніх світових тенденцій. Міжнародний стандарт також регламентує поняття "якості освіти" як сукупність властивостей і характеристик освітнього процесу, що задовольняють освітні потреби споживачів освітніх послуг.

Все це світоглядні поняття, які мають методологічне значення для забезпечення високої якості освіти на всіх етапах і рівнях.

Ключові слова: методологічний підхід; поняття "якість"; "якість освіти"; сутність; визначення; інтерпретація; трансформація понять; потреби, очікування споживачів.

UDC 37.012:001.891(045)

N. Holovko, PhD (Pedagogical Sciences), Associate Professor S. Balashova, PhD (Pedagogical Sciences), Associate Professor Taras Shevchenko National University of Kyiv, Kyiv, Ukraine

\section{FORMATION OF FUTURE TEACHER'S READINESS TO RESEARCH ACTIVITY AS A PEDAGOGICAL PROBLEM}

The article deals with theoretical aspects of formation of readiness of the future teacher for pedagogical research activity. To our mind research skills mean analytical-synthetic, informational, creative and prognostic skills, which integrate with the focus on research activities and personal qualities of the individual, provide its effective search-and-transformative activity in educational process.

Keywords: creativity, pedagogical creativity, research activity of the teacher, research skills.

Formulation of the problem. The transition from authoritarian pedagogy to the ideas of humanistic development of the individual, from the accumulation of knowledge as a self-sufficient process, to the development of the ability to operate them, from fragmentary education to continuous, from the frontal organization of training to individual needs the preparation of a teacher of new generation. Modern teacher must be prepared for innovation and creativity, have a variety of means of research at school, systematically replenish knowledge and apply a personally oriented approach in teaching activities. All this gives special importance to the problem of research pedagogical activity of a teacher. At the same time the growth of the requirements for professional training of the teacher requires a qualitatively new theoretical and methodological provision of student research activities in the institution of higher educational establishments. Successful mastery of research skills will help future teachers to organically engage in pedagogical activities and immediately begin the practical application of scientific knowledge in higher education establishments.
Research objective is to explore the theoretical aspects of forming the readiness of the future teacher to pedagogical research activities.

Analysis of recent researches and publications. Conceptual basis of professional training of the future teacher for creative activity is disclosed in the researches of V. Zagvyazinsky, I. Zyazyun, M. Nikandrov, M. Kukhariev, O.Savchenko, S.Sisoyeva and others. A special place belongs to the works of Ukrainian scientists which analyzes the professional training of future teachers in the context of personally oriented education and the preparation of a teacher for the introduction of innovative pedagogical technologies (I. Bekh, I. Bogdanova, I. Dichkivska, O. Pekhota, O. Pometun, O. Popova, P. Reshetnikov, M. Shevtsov, Y. Harlamov). The importance of the problem of preparing a future teacher for research pedagogical activity indicates and foreign experience is highlighted in the works of scientists G. Barton, C. Vederill, D. Ghalhaun, H. Gardner, P. Jarvis, D. Zhelo, J. Kreis, F. Cross, K. Minnie, H. Tomas, P. Hadson and others. 